\title{
Hazai mohafajok fitokémiai és farmakológiai vizsgálata
}

\author{
Vollár Martin ${ }^{1,2}$, Szücs Péter ${ }^{3}$, Marschall Marianna $^{3}$, Zupkó István $^{4}$, Gyovai András 4 , \\ Csupor-Löffler Boglárka ${ }^{1,2}$, Csupor Dezsö ${ }^{1,2}$ \\ ${ }^{1}$ Szegedi Tudományegyetem, Farmakognóziai Intézet, 6720 Szeged, Eötvös u. 6. \\ 2 Szegedi Tudományegyetem, Természetes Vegyületek Interdiszciplináris Központja, 6720 Szeged, \\ Eötvös u. 6. \\ ${ }^{3}$ Eszterházy Károly Egyetem, Növénytani és Növényélettani Tanszék, 3300 Eger, Lányka u. 6. \\ ${ }^{4}$ Szegedi Tudományegyetem, Gyógyszerhatástani és Biofarmáciai Intézet, 6720 Szeged, Eötvös u. 6.
}

A virágos növények mintegy 10-15\%-át vizsgálták valamilyen mértékben fitokémiai és farmakológiai szempontból, azonban a virágtalan, spórás felsőbbrendű növények közé tartozó mohákra kisebb tudományos figyelem irányult. Ugyanakkor a mohák másodlagos anyagcseretermékeinek vizsgálata érdeklődésre tarthat számot, mivel kór- és károkozókkal szembeni védekezésük hátterében citotoxikus és/vagy antimikróbás hatású vegyületek állhatnak.

Különböző mohafajokat elsősorban az ázsiai népi gyógyászatban alkalmaztak. Az amerikai őslakosok is használtak mohakivonatot hamuval keverve sebek kezelésére, Kínában pedig a mai napig megtalálhatók a gyógyászatban, külsőlegesen és belsőlegesen alkalmazva egyaránt. Az eddig vizsgált fajok jellemző vegyületei közé tartoznak mono- és szeszkviterpének, aromás észterek, növényi savak. Nagy felfedezésnek számít a korábban a Maytenus serrata kérgéből származó tubulingátló hatású maytanzinoidok azonosítása mohákból.

A hazai mohaflóra 659 fajt tartalmaz, ebből 58 fajt vizsgáltunk antiproliferatív és antimikrobiális hatásra in vitro szürővizsgálatban. Legaktívabbnak a Paraleucobryum longifolium bizonyult. Célunk ebből a fajból az aktív vegyületek izolálása és azonosítása. A preparatív növénykémiai munka során oszlopkromatográfiát, preparatív rétegkromatográfiát, rotációs planárkromatográfiát, közepes és nagy nyomású folyadékkromatográfiát alkalmazunk, normál és fordított fázisokon egyaránt. A szerkezetmeghatározás mágneses magrezonancia és tömegspektrometria segítségével történik.

Köszönetnyilvánítás: A kutatásokat az NKFI OTKA 115796 számú pályázati támogatása teszi lehetővé. A kutatás a Bolyai János Kutatási Ösztöndíj segítségével valósult meg.

Témavezető: $\quad$ Csupor Dezső (SZTE, Farmakognóziai Intézet) 